\title{
Indukálható bone morphogenetic protein 7 (BMP-7) termelő fogbél eredetú őssejtvonal létrehozása és vizsgálata
}

\author{
TÓTH FERENC*, DR. TŐZSÉR JÓZSEF**, DR. HEGEDŰS CSABA*
}

\begin{abstract}
A fogak pulpájából kinyerhető fogbél eredetű őssejtek olyan multipotens sejtek, amelyek többféle kötőszöveti sejttípussá képesek differenciálódni. Egyszerű izolálásuk és sejttenyészetekben történő fenntarthatóságuk többek között kívánatossá teszi szövetregenerációs folyamatokban donorként történő felhasználásukat is. A BMP-7 fehérje a TGF- $\beta$ szupercsalád tagja, növekedési faktor, amely fontos szerepet játszik az osteoblast irányú differenciálódás indukciójában, OP-1 néven rutinszerüen alkalmazzák gerincmútéteknél és hosszú csöves csontok törésének rögzítése során. Jelen munkánkban lentivirális géntranszferrel egy tetracyclinnel indukálható (Tet-ON) BMP-7 termelésre képes fogbél eredetű őssejtvonalat hoztunk létre, amelyben az expresszió mértéke a hozzáadott indukáló ágens (doxycyclin) mennyiségével szabályozható, annak megvonásával pedig megszüntethető. Reményeink szerint ez az indukálható BMP-7 expresszió elősegítheti, illetve felgyorsíthatja a környező sejtek csont irányú differenciálódását in vitro és in vivo egyaránt.
\end{abstract}

Kulcsszó: DPSC, BMP-7, lentivirális géntranszfer, Tet-ON, osteoblast

\section{Bevezetés}

Az indukálható transzgén expressziónak meghatározó jelentősége van a genetikailag módosított sejtek génexpressziójának szabályozásában [10,19], illetve a sejt alapú szövetépítés megjelenésével a szöveti regeneráció elősegítésében $[5,1,16,7]$. Ezekben az expressziós rendszerekben a transzgének expresszióját vezérlő promótereket nem emlős eredetű transzkripciós faktorok szabályozzák, külső forrásból érkező kémiai anyagok révén. Ezen rendszerek közül a leggyakrabban alkalmazottak és leginkább jellemzettek a tetracyclinnel szabályozható expressziós rendszerek, amelyeket Gossen és Bujardt írt le először 1992-ben [9]. Ezeket a rendszereket használták már korábban a csontképződésben szerepet játszó transzgének expressziójára is [17, 8].

Csontszövet-regenerációs célokra a legjobb választás a mesenchymális őssejtek használata, azok - a korábban elterjedt differenciált sejttípusokhoz (pl. myoblast, fibroblast) viszonyított - rövidebb differenciálódási útvonala miatt [2]. A mesenchymális őssejtek legkönnyebben, nem invazív módszerrel hozzáférhető forrása az egyéb egészségügyi célokból kihúzásra kerülő bölcsességfogak pulpája [11]. Az ezekből kinyerhető multipotens fogbél eredetű őssejtek többféle kötőszöveti sejttípus irányába differenciáltathatók, egyszerű izolálhatóságuk mellett sejttenyészetben könnyen fenntarthatók, felhasználásukig fagyasztva tárolhatók, ennél fogva terápiás felhasználásuk lehetőségei igen széleskörűek [25, 24].

Az osteoblast irányú differenciálódás indukciója és szabályozása a megfelelő növekedési és differenciálódási faktorok jelenlétének függvénye. Ezen faktorok génjei génterápiás technikák felhasználásával bejuttathatók a sejtekbe, ezáltal az adott sejt képessé válik a transzgén (over) expressziójára, így az osteoblast irányú differenciálódásra és in vivo csontképzésre $[28,3,6]$. Azonban a faktorok szabályozás nélküli expressziója magában foglalja a tumorképződés [12, 21] és az abnormális csontképződés $[18,20]$ veszélyét is. Erre a problémára az indukálható génexpresszió jelenthet megoldást, ahol a sejtek csak az indukáló ágens jelenlétében expresszálják a transzgént, annak megvonásával visszatérnek az alap állapotba, megelőzve így a hoszszan tartó expresszióból kialakuló káros hatásokat.

A transforming growth factor- $\beta$ (TGF- $\beta$ ) szupercsaládba tartozó BMP-7 fehérje növekedési faktor, jelentős szerepet játszik több szövet és szerv - közöttük a fogak kialakulásának folyamatában [26, 30], illetve a mesenchymalis őssejtek osteoblast irányú differenciálódásában [15, 29, 22], ezáltal fontos szerepe van a csontszövet regenerációjában [31].

Jelen munkánk célja egy indukálható BMP-7 transzgén és ezzel kapcsoltan zöld fluoreszcens fehérje (GFP) expressziójára képes fogbél eredetű őssejt (DPSC) vonal létrehozása volt, amelyhez egy génterápiás, lentivirális vektorrendszert használtunk fel. Az ilyen módon létrehozott sejtekben a transzgén expressziója doxycyclin jelenlétében aktiválódik, és annak megvonásával kapcsolható ki. Az expresszió mértéke a hozzáadott doxycyclin menynyiségével szabályozható. 


\section{Vizsgálati anyag és módszer}

Fogbél eredetú őssejtek izolálása, és tenyésztése A fogbél eredetú őssejtek izolálását, illetve a sejteken végzett kísérleteket az ETT TUKEB 49849-3/2016/EKU ügyiratszámú engedély birtokában végeztük el.

A fogbél eredetű őssejtek izolálásához a Debreceni Egyetem Fogorvostudományi karán ellátott páciensekből sebészi úton eltávolított, sértetlen bölcsességfogakat használtuk. A fogakat $10 \%$ fötális marhaszérumot (FBS) (Gibco, Waltham, MA, Egyesült Államok), 1\% Antibiotic-Antimycotic (penicillin, streptomycin, amphotericin B) oldatot (Gibco, Waltham, MA, Egyesült Államok) és $1 \%$ Glutamax (Gibco, Waltham, MA, Egyesült Államok) kiegészítést tartalmazó DMEM F12 (Gibco, Waltham, MA, Egyesült Államok) tenyésztő médiumba helyeztük. A fogak szeparálása és kettérepesztése után a pulpát eltávolítottuk, steril szikével feldaraboltuk, majd egy órán át emésztettük $37 \mathrm{C}^{\circ}$-on, $3 \mathrm{mg} / \mathrm{ml}$ kollagenáz (Sigma Aldrich, St. Louis, MO, Egyesült Államok) és $4 \mathrm{mg} / \mathrm{ml}$ diszpáz (Gibco, Waltham, MA, Egyesült Államok) enzimet tartalmazó tenyésztő médiumban. A mintákat emésztés közben 15 percenként vortexeltük, majd az inkubáció után centrifugáltuk 5 percig 1200 RPM-en. A lecentrifugált sejtekről a felülúszót eltávolítottuk, a sejteket tenyésztó médiumban szuszpendáltuk, majd 6 lyukú sejttenyésztő lemez egyik lyukába ültettük ki. Az izolált sejteket $37 \mathrm{C}^{\circ}$-on $5 \% \mathrm{CO}_{2}$ tartalom mellett tenyésztettük nagyobb tenyésztő edénybe történő áthelyezésükig. A tenyésztő médiumot kétnaponta cseréltük. A sejteket a harmadik passzálás után használtuk fel a transzdukcióhoz.

\section{A BMP-7 gén klónozása}

A BMP-7 fehérjét kódoló, a széleken BamHI hasítóhelyet tartalmazó génszakaszt (Genscript, Piscataway, NJ, Egyesült Államok) T4 ligáz enzim (New England Biolabs, Ipswich, MA, Egyesült Államok) segítségével illesztettük be a pTet-IRES-EGFP plazmid [23] (Addgene plasmid \# 64238) BamHI klónozó helyére. A pTet-IRESEGFP plazmid Maria Lung (University of Hong Kong, Department of Clinical Oncology) ajándéka. Az elkészült pTet-IRES-BMP7 plazmidot Stbl3 kompetens E. coli sejtekbe (Invitrogen, Carlsbad, CA, Egyesült Államok) transzformáltuk, amelyet aztán $100 \mathrm{mg} / \mathrm{ml}$ ampicillint tartalmazó agarózra szélesztettünk és növesztettük fel. A kinőtt telepekből éjszakai kultúrát indítottunk, amelyből azután plazmidot preparáltunk Monarch Plasmid Miniprep Kit (New England Biolabs, Ipswich, MA, Egyesült Államok) segítségével, majd 5'-AGAGCTCGTTTAGTGAACCG-3', 5'-AACGCACACCGGCCTTATTC-3' és 5'-CTACCACCATCGAGAGTTCC -3' oligonukleotidok alkalmazásával szekvenáltuk annak igazolására, hogy a plazmidunk helyes orientációban tartalmazza a kívánt BMP-7 fehérjét kódoló génszakaszt. $A$ DNS szekvenálást $A B I$ Prism Dye terminator cycle sequencing kit és 3100-Avant Genetic Analyzer (mindkettő Applied Biosystems, Fos- ter City, CA, Egyesült Államok) készülék használatával végeztük.

\section{Lentivírus-termelés és transzdukció}

A vírusrészecskék előállításához humán embrionális vesesejtekből származó Lenti-X 293T sejteket (Clontech Laboratories, Mountain View, CA, Egyesült Államok) használtunk, amelyeket $10 \%$ FBS, $1 \%$ antibiotic/ antimycotic (Gibco, Waltham, MA, Egyesült Államok) és $1 \%$ Glutamax (Gibco, Waltham, MA, Egyesült Államok) kiegészítést tartalmazó Dulbecco's modified Eagle's (DMEM) (Invitrogen, Carlsbad, CA, Egyesült Államok) médiumban tartottunk fent. A sejteket polietilénimin (Sigma Aldrich, St. Louis, MO, Egyesült Államok) segítségével transzfektáltuk. A sejteket addig növesztettük, míg megközelítőleg $70 \%$-ban borították be a $75 \mathrm{~cm}^{2}$-es tenyésztőflaska alját és ekkor végeztük el a transzfekciót. A lentivirális pTet-IRESEGFP, pTet-IRES-BMP7 vagy pLenti CMV rtTA3 blast plazmidokat, a psPAX2 (Addgene plasmid 12260) csomagoló plazmidot és a pMD2.g (Addgene plasmid 12259) envelop plazmidot 4:3:1 arányban összekevertük. A transzfekciót 1\% FBS tartalmú DMEM médiumban hajtottuk végre, amit 6 óra elteltével 10\% FBS tartalmú médiumra cseréltünk. A sejteket a transzfekció után 3 napig tartottuk a tenyésztő médium cseréje nélkül. A vírusrészecskéket tartalmazó kondicionált médiumot centrifugáltuk azért, hogy eltávolítsuk a sejttörmeléket, majd 0,45 $\mu \mathrm{m}$ pórusméretű PVDF fecskendőszűrőn (Merck Millipore, Billerica, MA, Egyesült Államok) átszűrtük és szétporciózva $-70{ }^{\circ} \mathrm{C}$-on tároltuk.

A sejtek 6 lyukú sejttenyésztő lemezen történő transzdukciójához 6 lyukú sejttenyésztő lemezre lyukanként $10^{5}$ darab fogbél eredetű őssejtet ültettünk ki. A következő napon $500 \mu \mathrm{l}$ pLenti CMV rtTA3 Blast vírusrészecskét, $500 \mu \mathrm{l}$ pTet-IRES-EGFP (mock kontroll) vagy $p$ Tet-IRES-BMP7 vírusrészecskét és $1 \mathrm{ml}$ üres DMEM F12 médiumot $8 \mu \mathrm{g} / \mathrm{ml}$ végső koncentrációjú polibrénnel (Sigma Aldrich, St. Louis, MO, Egyesült Államok) kevertünk össze, a sejtekre mértük és 16 órán keresztül inkubáltuk. Ezután a transzfekciós elegyet friss tenyésztő médiumra cseréltük. Az első passzálás után a sejteket 5 napig a médiumhoz adott $4 \mu \mathrm{g} / \mathrm{ml}$ koncentrációjú blaszticidinnel (Gibco, Waltham, MA, Egyesült Államok) kezeltük, hogy eltávolítsuk a pLenti CMV rtTA3 Blast vírusrészecskékkel nem transzdukált sejteket. Az antibiotikumos szelekció után a tenyésztő médiumhoz adott doxycyclinnel (Sigma Aldrich, St. Louis, MO, Egyesült Államok) indukáltuk a sejtek zöld fluoreszcens fehérje (GFP) és BMP-7 termelését, majd a sejteket fluoreszcens mikroszkóppal (Zeiss Axiovert 100, Carl Zeiss Microscopy, Jena, Németország) és áramlási citometriával (BD FACSCalibur, BD Biosciences, Franklin Lakes, NJ, EgyesültÁllamok) vizsgáltuk azért, hogy megállapítsuk a transzdukció hatékonyságát. 


\section{Génexpresszió vizsgálata}

$4 \times 10^{4}$ sejtet ültettünk ki 24 lyukú sejttenyésztő lemez megfelelő számú lyukába. A következő napon a sejtekből mintát vettünk, majd a tenyésztő médiumot lecseréltük friss, megfelelő összetételú médiumokra (tenyésztő vagy differenciáló) $100 \mathrm{ng} / \mathrm{ml}$ doxycyclin hozzáadásával, vagy anélkül. Az 1., 4. és 7 . napokon a sejtekből újabb mintát vettünk és mRNS-t vontunk ki Quick-RNA Miniprep kit segítségével (Zymo Research, Irvine, CA, Egyesült Államok) a gyártó utasításai szerint. Mintánként 200 ng mRNS került átírásra High Capacity cDNA Reverse Transcription kit (Applied Biosystems, Foster City, CA, Egyesült Államok) alkalmazásával. Az elkészült cDNS mintákon kvantitatív PCR analízist végeztünk LightCycler 480 (HoffmannLa Roche, Bázel, Svájc) készülék segítségével, HOT Firepol Probe qPCR mix (Solis BioDyne, Tartu, Észtország) és génspecifikus TaqMan reagensek használatával. A mérési eredményeket glicerinaldehid-3-foszfátdehidrogenáz (GAPDH) háztartási gén expressziójára normalizáltuk. A kísérleteket időpontonként három párhuzamos mintával végeztük, a qPCR vizsgálatban egy minta három technikai ismétléssel került lemérésre.

\section{BMP-7 immunoblott}

$2 \times 10^{5}$ sejtet ültettünk ki 53 mm átmérőjű sejttenyésztő petricsészékbe. A következő napon a sejteken a tenyésztő médiumot friss médiumra cseréltük 3,125 ; 6,$25 ; 12,5 ; 25 ; 50 ; 100$ illetve $200 \mathrm{ng} / \mathrm{ml}$ doxycyclin hozzáadásával, vagy anélkül. A sejteken kétnaponta médiumot cseréltünk, a 6 . napon $10 \mu \mathrm{g} / \mathrm{ml}$ Brefeldin A (Tocris Bioscience, Bristol, Egyesült Királyság) hoz-
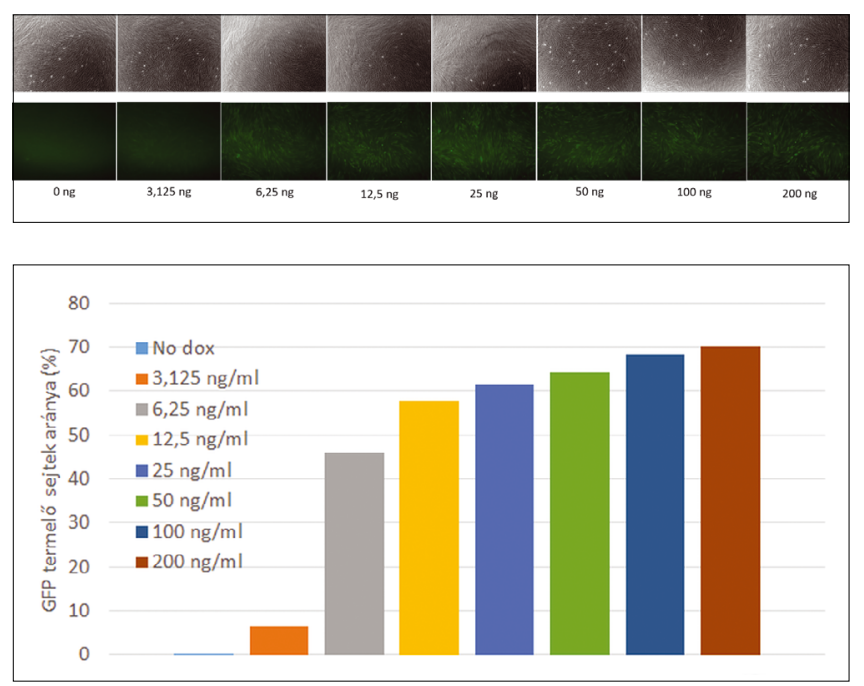

1. kép: Dózisfüggő GFP expresszió DPSC sejtekben. Az egy páciensből származó DPSC sejteket pLenti CMV rtTA3 blast és pTet-IRES-BMP7 plazmidot tartalmazó vírusrészecskékkel transzdukáltuk, majd blaszticidines szelekció után különböző koncentrációjú doxycyclinnel voltak kezelve $(3,125 ; 6,25 ; 12,5 ; 25 ; 50 ; 100$ és $200 \mathrm{ng} / \mathrm{ml})$.

(A) Reprezentatív mikroszkópos felvételek a különböző koncentrációjú doxycyclinnel kezelt DPSC-BMP7 sejtekről.

(B) GFP termelő sejtek százalékos arányának meghatározása áramlási citometriával. záadásával gátoltuk az endoplazmatikus retikulumból a golgi-készülékbe történő fehérjeszállítást. A 7. napon a sejteket radioimmuno-precipitation assay puffer $(150 \mathrm{mM} \mathrm{NaCl} ; 1 \%$ Triton $\mathrm{X}-100 ; 0,5 \%$ nátrium deoxycholate; $0,1 \%$ SDS; $50 \mathrm{mM}$ Tris- $\mathrm{HCl}$ és $1 \%$ proteáz inhibítor koktél; $\mathrm{pH} 8$ ) segítségével lizáltuk. A sejtlizátumok fehérjekoncentrációját BCA protein assay kit segítségével határoztuk meg. Mintánként $20 \mu \mathrm{g}$ fehérjét választottunk el 10\%-os TGX Stain-Free ${ }^{\mathrm{TM}}$ FastCast ${ }^{\mathrm{TM}}$ akrilamid gélen (Bio-Rad Laboratories, Hercules, CA, Egyesült Államok), majd az elválasztott fehérjéket polivinil-fluorid (PVDF) membránra (Bio-Rad Laboratories) blottoltuk át. A membránokat $5 \%$ tejport tartalmazó Tris Buffered Saline with Tween 20 pufferrel (TBST) blokkoltuk, majd 400x-os higítású BMP-7 (Santa Cruz Biotechnologies, Dallas, TX, Egyesült Államok), illetve 5000x-es higítású GAPDH (LifeSpan Biosciences, Seattle, WA, Egyesült Államok) elleni antitesttekkel inkubáltuk egy éjszakán át. A mosási lépések után 2000x-es higítású anti-mouse HRP (Thermo Fisher Scientific, Waltham, MA, Egyesült Államok) másodlagos antitesttel inkubáltuk 1 óráig szobahőmérsékleten és az immunoblottokat BMP-7 esetében SuperSignal $\circledast$ West Femto Maximum Sensitivity Substrate, a GAPDH

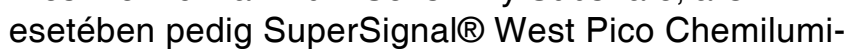
nescent Substrate használatával hívtuk elő a gyártó utasításai szerint. Az eredményeket ChemiDoc ${ }^{\mathrm{TM}}$ Touch Imaging System (Bio-Rad Laboratories) segítségével detektáltuk.

\section{Eredmények}

\section{A transzdukált sejtek GFP expressziója}

doxyciklin dózisfüggést mutat

A pLenti CMV rtTA3 blast és pTet-IRES-BMP7 plazmidot tartalmazó vírusrészecskékkel transzdukáltunk DPSC sejteket, majd az antibiotikumos szelekció után 3,125 ng/ml-töl 200 ng/ml-es doxycyclin koncentrációig terjedő tartományban vizsgáltuk a sejtek GFP termelését fluoreszcens mikroszkópia és áramlási citometria alkalmazásával.

Ahogy az 1. képen is megfigyelhető, a DPSC-BMP7 sejtek GFP expressziója dózisfüggést mutat. A doxycyclinkoncentráció és a GFP jel kapcsolata szigmoid görbével írható le. A bazálisan GFP-t termelő sejtek száma nagyon alacsony, nem éri el az 1\%-ot, a doxycyclinkoncenmennyiség növelésével együtt növekszik, $200 \mathrm{ng} / \mathrm{ml}$-es doxycyclinkoncentrációnál már a sejtek 70\%-a termel GFP-t. A koncentráció további növelése már nem okoz számottevő változást.

\section{A BMP-7 mRNS szintje jelentös növekedést mutat az indukált DPSC-BMP7 sejtekben}

A BMP-7 transzgén expresszió működésének, illetve a bazális transzgénexpresszió szintjének vizsgálatához a sejteket tenyésztő médiumban növesztettük $100 \mathrm{ng} /$ $\mathrm{ml}$ doxycyclin hozzáadásával, vagy anélkül. 1., 4. és 
7. nap elteltével vizsgáltuk a sejtek BMP-7 mRNS szintjének változását, majd az eredményeket a GAPDH háztartási génre normalizáltuk.

Megfigyeléseink szerint az indukált sejtekben 24 órával az indukció után a BMP-7 mRNS szintje a nem indukált sejtekben mért szint ötszörösére, egy hét után pedig annak harmincnyolcszorosára növekszik (2. kép). Ezek alapján elmondható, hogy a sejtek doxycyclinnel történő kezelése hatékonyan indukálja a BMP-7 transzgén expresszióját, amelyhez viszonyítva a kezeletlen sejtek expressziója nem mutat számottevő változást.

\section{A BMP-7 fehérje mennyisége}

a sejtekben doxyciklin dózisfüggést mutat

A BMP-7 fehérje expresszió szintjének vizsgálatához a sejteket, $0 ; 3,125 ; 6,25 ; 12,5 ; 25 ; 50 ; 100$ és $200 \mathrm{ng} / \mathrm{ml}$ doxycyclin hozzáadásával tenyésztettük. 7 nap elteltével vizsgáltuk a sejtekben található BMP-7 fehérje mennyiségének változását. A GAPDH fehérje kimutatásával igazoltuk, hogy azonos mennyiségű fehérjét vittünk fel a gélekre.

$A z$ indukált sejtekben 7 nappal az indukció után a BMP-7 fehérje szintje különböző mértékben növekedett a hozzáadott doxycyclin mennyiségétől függően (3. kép). Ezek alapján elmondható, hogy a sejtek doxycyclinnel történő kezelése sikeresen indukálja a BMP-7 fehérje termelődését, miközben a kezeletlen sejtekben nem található detektálható mennyiségű fehérje. A növekedés a GFP termeléshez hasonlóan változik, a $12,5 \mathrm{ng} / \mathrm{ml}$-es koncentrációig nagy léptékben növekszik, ám a koncentráció további növelése már nem okoz nagymértékủ változást.

\section{Megbeszélés}

A csontszövet újraépítésére különböző differenciált sejttípusok mellett [4] alternatívát kínál az embrionális őssejtek használata, amelyek rövidebb differenciálódási útvonala [2] gyorsabb regenerációt is lehetővé tehet. A bölcsességfogak pulpájából izolált mesenchymális őssejtek kedvező tulajdonságaik miatt igen ígéretes választásnak bizonyulhatnak erre a célra.

A csont irányú differenciálódás indukciójában a megfelelő növekedési faktorok jelenléte meghatározó jelentőséggel bír, a megfelelő helyre történő eljuttatásuk alapvető fontosságú a regenerációs folyamatok elindításához. Ezek a sejtek azonban stabil indukciót igényelnek, hogy elkerüljük a de-differenciációt vagy nemkívánatos sejttípussá történő transz-differenciációt és a tumorok keletkezését [14]. A problémára megoldást jelent a génterápiás technikák felhasználása, amelylyel a megfelelő faktorok génjei a sejtekbe bejuttathatók, ami által azok képessé válnak az adott transzgén expressziójára.

Korábban John Yau és munkatársai [13] nem virális eredetű BMP-7 gént kódoló vektorral transzfektáltak humán fogbél eredetű sejteket, amelynek eredményeként

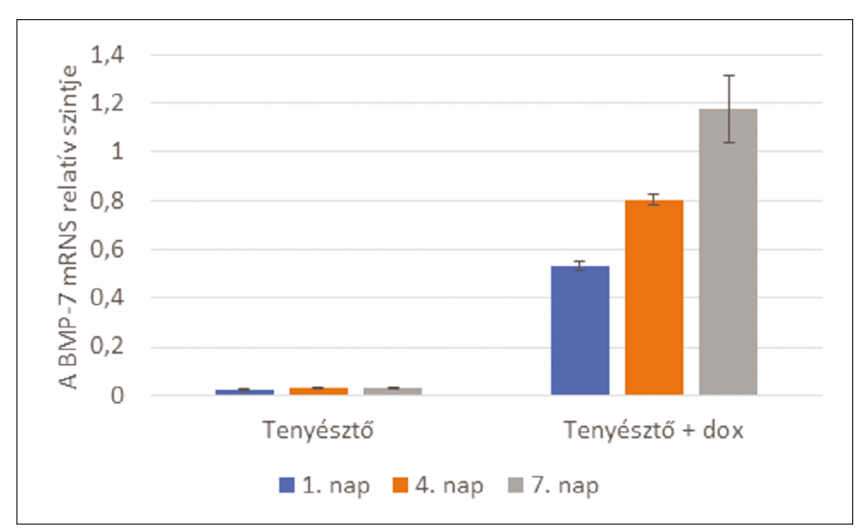

2. kép: Doxycyclin által indukált relatív BMP-7 génexpresszió változás.

A transzgén expresszió változásai kvantitatív Real-Time módszerrel mértük meg DPSC-BMP7 sejtekben doxycyclin hozzáadásával, illetve anélkül. Az eredményeket a GAPDH háztartási gén expressziójára normalizáltuk.

A hibasávok a szórás értékét jelzik $(n=3)$.

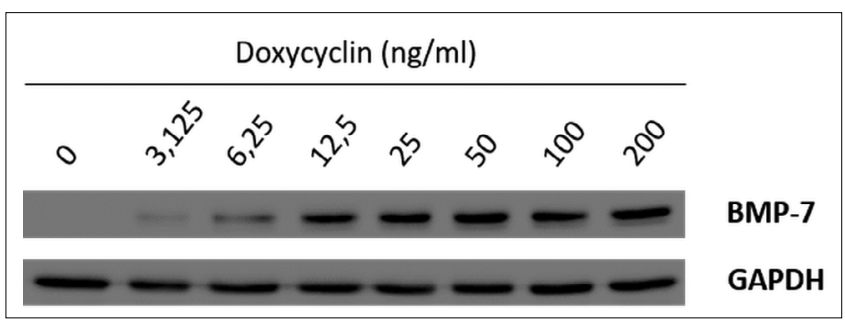

3. kép: Dózisfüggő BMP-7 expresszió. $A z$ in vitro BMP-7 expresszió western blot képe a különböző koncentrációjú doxycyclinnel kezelt sejtekben. A GAPDH fehérje expresszió western blot képe igazolja, hogy azonos mennyiségű összfehérje került felvitelre az akrilamid gélre.

az általuk vizsgált csont irányú differenciáció markereinek (alkalikus foszfatáz, osteocalcin) relatív szintje megnövekedett. Módszerük alkalmas lehet a sejtek ex-vivo differenciálására, ami után a sejtek terápiás felhasználása is szóba kerülhet. Az ilyen módszerrel a sejtekbe bejuttatott vektor azonban csak rövidtávon használható, idővel lebontódik, eltávolításra kerül, ezért munkánk során egy stabil géntranszferre képes lentivirális vektorrendszert használtunk a BMP-7 transzgén sejtekbe történő bejuttatására. További veszélyt jelenthet még a gének szabályozás nélküli expressziója is [12, 18, 20,21], amelyet indukálható génexpresszió alkalmazásával kívántuk megoldani.

Munkánk során sikeresen klónoztuk a BMP-7 transzgént a lentivirális vektorrendszerbe, amely rendszerben ez a transzgén igény szerint cserélhető, általa további gének szerepének vizsgálata válik lehetővé. A vektorrendszer igen nagy transzdukciós hatékonysággal bír, áramlási citometriás méréseink szerint a doxycyclinnel kezelt, transzdukált sejtek $70 \%$-a expresszálja a GFP marker fehérjét. A doxycyclinnel indukált sejtekben már 24 óra után jelentősen emelkedik a BMP-7 mRNS szintje 
a kezeletlen sejtekben mértekhez képest, amely növekedés a későbbiekben tovább fokozódik. A marker (GFP), illetve a BMP-7 transzgén expressziója a hozzáadott doxycyclin mennyiségétől függően szabályozható, amelyet az áramlási citometriás mérések és a BMP-7 immunoblott kísérletek egyaránt alátámasztanak. Denzitometriás méréseink szerint a marker és a transzgén expressziójának változása egymással nem vethető össze, ugyanis, míg a GFP termelés növekedése egészen a $200 \mathrm{ng} / \mathrm{ml}$-es doxycyclin koncentrációig nyomon követhető, a BMP. 7 mennyisége az $50 \mathrm{ng} / \mathrm{ml}$ doxycyclin koncentráció alkalmazásakor éri el maximumát, ezután csökkenést mutat. A jelenség okát jelenleg nem ismerjük, ugyanis bár a BMP-7 aktivitásnak számos intra- (Smad 6/7, hepatocyta növekedési faktor) és extracelluláris inhibitora (chordin, noggin, DRM/gremlin és sclerostin) ismert [27], sőt magának a doxycyclinnek is ismert ilyen hatása, azonban az, hogy ezek hogyan képesek befolyásolni a BMP-7 expressziót, pillanatnyilag ismeretlen.

Jelen kutatásunkban létrehoztunk egy olyan fogbél eredetű őssejt vonalat, amely doxycyclines indukciótól függően képes a BMP-7 fehérje szabályozott expressziójára, így közvetlenül vizsgálhatjuk a sejtvonalra kifejtett hatását. Várakozásaink szerint ez a sejtvonal önálló BMP-7 termelésén keresztül képes lehet a környező sejtek osteoblast irányú differenciálódásának indukciójára, illetve a folyamat felgyorsítására is. A későbbiekben in vivo a sejteket donorként használhatjuk, amely által felgyorsíthatóvá válhat a különféle csonttal kapcsolatos sérülések regenerációja. A BMP-7 génexpresszió indukálhatósága folytán elkerülhetővé válnak a túlzott idejú génexpresszióból származó káros hatások is.

\section{Irodalom}

1. Albuquerque MtP, Valera MC, Nakashima M, Nör Je, Bottino MC: Tissue-engineering-based strategies for regenerative endodontics. J Dent Res. 2014: 1222-1231.

2. Almadlaq A, Mao JJ: Tissue-Engineered Osteochondral Constructs in the Shape of an Articular Condyle. J Bone Jt Surg. 2005: 936-944.

3. BaLtZer AWA, Lieberman JR: Regional gene therapy to enhance bone repair. Gene Ther. 2004: 344-350.

4. Bianco P, Riminucci M, Gronthos S, Robey PG: Bone marrow stromal stem cells: nature, biology, and potential applications. Stem Cells. 2001: 180-192.

5. Bruder SP, Fox BS: Tissue engineering of bone. Cell based strategies. Clin Orthop Relat Res. 1999: S68-83.

6. Dunn CA, Jin Q, Taba M, Franceschi RT, Bruce Rutherford R, GlANNOBILE WV ET AL: BMP gene delivery for alveolar bone engineering at dental implant defects. Mol Ther. 2005: 294-299.

7. Fisher JN, Peretti GM, Scotti C: Stem Cells for Bone Regeneration: From Cell-Based Therapies to Decellularised Engineered Extracellular Matrices. 2016.

8. Gersbach CA, Le Doux JM, Guldberg RE, García AJ: Inducible regulation of Runx2-stimulated osteogenesis. Gene Ther. 2006: 873

9. Gossen M, Bujardt $\mathrm{H}$ : Tight control of gene expression in mammalian cells by tetracycline-responsive promoters. Cell Biol J Gehring. 1992: 5547-5551.

10. Goverdhana S, Puntel M, Xiong W, Zirger JM, Barcia C, Curtin JF ET AL: Regulatable gene expression systems for gene therapy applications: Progress and future challenges. Mol Ther. 2005: 189-211.
11. Gronthos S, Mankani M, Brahim J, Robey PG, Shi S: Postnatal human dental pulp stem cells (DPSCs) in vitro and in vivo. Proc Natl Acad Sci U S A. 2000: 13625-13630.

12. Ide H, Yoshida T, Matsumoto N, Aoki K, Osada Y, Sugimura T et al: Growth Regulation of Human Prostate Cancer Cells by Bone Morphogenetic Protein-2'. CANCER Res. 1997: 5022-5027.

13. John Yau KP, Zuo P, Rabie ABM, Wong R: BMP7 transfection induces in-vitro osteogenic differentiation of dental pulp mesenchymal stem cells. APOS Trends Orthod. 2013: 9-14.

14. Lee RH, KIm B, ChOI I, KIm H, ChO HS, SuH K et AL: Characterization and Expression Analysis of Mesenchymal Stem Cells from Human Bone Marrow and Adipose Tissue. Cell Physiol Biochem. 2004: 311-324.

15. Li T, Surendran K, Zawaideh MA, Mathew S, Hruska Ka: Bone morphogenetic protein 7: a novel treatment for chronic renal and bone disease. Curr Opin Nephrol Hypertens. 2004: 417-422.

16. Ma J, Both SK, Yang F, Cui F-Z, Pan J, MeiJer GJ et al: Concise review: cell-based strategies in bone tissue engineering and regenerative medicine. Stem Cells Transl Med. 2014: 98-107.

17. Moutsatsos IK, Turgeman G, Zhou S, Kurkalli BG, Pelled G, Tzur L ET AL: Exogenously Regulated Stem Cell-Mediated Gene Therapy for Bone Regeneration strate that regulated gene expression in mesenchymal stem cells can be used as a means to control. 2001: 449-461.

18. Moutsatsos IK, Turgeman G, Zhou S, Kurkalli BG, Pelled G, Tzur L ET AL: Exogenously Regulated Stem Cell-Mediated Gene Therapy for Bone Regeneration. Mol Ther. 2001: 449-461.

19. NAIDOO J, Young D: Gene regulation systems for gene therapy applications in the central nervous system. Neurol Res Int. 2012.

20. Peng H, Usas A, Hannallah D, Olshanski A, Cooper GM, Huard J: Noggin Improves Bone Healing Elicited by Muscle Stem Cells Expressing Inducible BMP4. Mol Ther. 2005: 239-246.

21. Pouliot F, Blais A, Labrie C: Overexpression of a Dominant Negative Type II Bone Morphogenetic Protein Receptor Inhibits the Growth of Human Breast Cancer Cells 1. CANCER Res. 2003: 277-281.

22. Rabie A-B, Wong R, Zuo P, John Yau K: BMP7 transfection induces in-vitro osteogenic differentiation of dental pulp mesenchymal stem cells. APOS Trends Orthod. 2013: 9.

23. Shuen WH, Kan R, Yu Z, Lung HL, Lung ML: Novel lentiviral-inducible transgene expression systems and versatile single-plasmid reporters for in vitro and in vivo cancer biology studies. Cancer Gene Ther. 2015: 1-8.

24. Takeda-Kawaguchi T, Sugiyama K, Chikusa S, IIda K, Aoki H, TamaOKI N ET AL: Derivation of ipscs after culture of human dental pulp cells under defined conditions. PLOS One. 2014: 1-15.

25. Tamaoki N, Takahashi K, Tanaka T, Ichisaka T, Aokı H, TakedaKAWAGUCHI T ET AL: Dental pulp cells for induced pluripotent stem cell banking. J Dent Res. 2010: 773-778.

26. ThesLefF I, SHARPE P: Signalling networks regulating dental development. Mech Dev. 1997: 111-123.

27. Tsialogiannis E, Polyzois I, Oak Tang Q, Pavlou G, Tsiridis E, HeLIOTIS M ET AL: Targeting bone morphogenetic protein antagonists: in vitro and in vivo evidence of their role in bone metabolism. $E x$ pert Opin Ther Targets. 2009: 123-137.

28. Tsuda H, Wada T, Ito Y, Uchida H, Dehari H, Nakamura K et al: Efficient BMP2 gene transfer and bone formation of mesenchymal stem cells by a fiber-mutant adenoviral vector. Mol Ther. 2003: 354-365.

29. Xue Z, Niu L-Y, An G, Guo Y-S, Lv S-C, Ren X-P: Expression of recombinant BMP-7 gene increased ossification activity in the rabbit bone mesenchymal stem cells. Eur Rev Med Pharmacol Sci. 2015: 3056-3062.

30. YE L, Bokobza SM, JIANG WG: Bone morphogenetic proteins in development and progression of breast cancer and therapeutic potential (review). Int J Mol Med. 2009: 591-597.

31. Zhang Y, Song J, Shi B, Wang Y, Chen X, Huang C et al: Combination of scaffold and adenovirus vectors expressing bone morphogenetic protein-7 for alveolar bone regeneration at dental implant defects. Biomaterials. 2007: 4635-4642. 
Tóth F, TőZsér J, Hegedüs C

\section{Establishment and examination of an inducible bone morphogenetic protein 7 (BMP-7) expressing dental pulp stem cell line}

Dental pulp stem cells (DPSC) from extracted adult teeth are multipotent cells which are capable of differentiation into various connective-tissue cell lineages, including osteoblasts and odontoblasts. DPSC can be safely cryopreserved, and easily maintained in cell cultures, therefore, their use as a donor in tissue engineering and regeneration procedures is an attractive alternative. The BMP-7 protein is member of the transformation growth factor (TGF)- $\beta$ superfamily of growth factors, known to act as an inducer of osteoblast differentiation in vitro and in vivo. Human recombinant BMP-7 is already used in the fusion of vertebral bodies, and in the treatment of tibial non-union under the brand name OP-1. The aim of this work was the establishment of an inducible BMP-7 expressing cell line. To generate an efficient and regulated transgene expression, we utilized a second generation lentiviral tet-on gene expression system to modulate BMP-7 expression. It was demonstrated, that the cell line is capable of induced BMP-7 expression, the expression of which is doxycyclin dose-dependent, and can be aborted upon cessation of doxycycline treatment. The leakage of the system in the absence of doxycycline is negligible. We intend to use this cell line to investigate the effect of inducible BMP-7 gene expression on the osteogenic differentiation of DPSC, a potent donor cell line in tissue engineering.

Keywords: DPSC, BMP-7, lentiviral gene transfer, Tet-On, osteoblast 